\title{
Effects of foliar application of melatonin on gas exchange and certain biochemical characteristics broccoli cv. Palam Samridhi
}

\section{Mansha Gul}

Division of Basic Sciences and Humanities, Sher-e-Kashmir University of Agricultural Sciences and Technology of Kashmir, Shalimar, Distt. Srinagar - 190025 (J\&K), India

\section{F. A. Khan}

Division of Basic Sciences and Humanities, Sher-e-Kashmir University of Agricultural Sciences and Technology of Kashmir, Shalimar, Distt. Srinagar - 190025 (J\&K), India

\section{Shafiq A Wani}

Directorate of Research, Sher-e-Kashmir University of Agricultural Sciences and Technology of Kashmir, Shalimar, Distt. Srinagar - 190025 (J\&K), India

\section{S. A. Bhat}

Division of Basic Sciences and Humanities, Sher-e-Kashmir University of Agricultural Sciences and Technology of Kashmir, Shalimar, Distt. Srinagar - 190025 (J\&K), India

\section{S. A. Mir}

Division of Agri-Statistics, Sher-e-Kashmir University of Agricultural Sciences and Technology of Kashmir, Shalimar, Distt. Srinagar - 190025 (J\&K), India

\section{A. Malik}

Division of Vegetable Science, Sher-e-Kashmir University of Agricultural Sciences and Technology of Kashmir, Shalimar, Distt. Srinagar - 190025 (J\&K), India

\section{Amit Kumar}

Division of Fruit Science, Sher-e-Kashmir University of Agricultural Sciences and Technology of Kashmir, Shalimar, Distt. Srinagar - 190025 (J\&K), India

\section{S. Narayan}

Division of Vegetable Science, Sher-e-Kashmir University of Agricultural Sciences and Technology of Kashmir, Shalimar, Distt. Srinagar - 190025 (J\&K), India

\section{Moinuddin*}

Department of Agriculture, Shri Guru Ram Rai University, Dehradun (Uttarakhand), India

\section{Fasil Fayaz}

Division of Basic Sciences and Humanities, Sher-e-Kashmir University of Agricultural Sciences and Technology of Kashmir, Shalimar, Distt. Srinagar - 190025 (J\&K), India ; Department of Agriculture, Shri Guru Ram Rai University, Dehradun (Uttarakhand)

\section{S. A. Lone}

Division of Basic Sciences and Humanities, Sher-e-Kashmir University of Agricultural Sciences and Technology of Kashmir, Shalimar, Distt. Srinagar - 190025 (J\&K), India

*Corresponding author. Email: drkhan_387@skuastkashmir.ac.in

\section{Article Info}

https://doi.org/10.31018/ jans.v13i2.2673

Received: April 18, 2021

Revised: June 7, 2021

Accepted: June 10, 2021

\section{How to Cite}

Gul, M. et al. (2021). Effects of foliar application of melatonin on gas exchange and certain biochemical characteristics broccoli cv. Palam Samridhi. . Journal of Applied and Natural Science, 13(2), 791 - 797. https://doi.org/10.31018/jans.v13i2.2673

\begin{abstract}
Considering the rich nutritional status and possibility of broccoli in improving the profitable yield, and wide role of Mel in regulating the plant physiological process, an investigation was carried out at the division of Basic Sciences and Humanities during 2017 to investigate the effect of foliar application of Mel on leaf photosynthetic and biochemical attributes broccoli. Thirty days old and uniform seedlings of broccoli cv. Palam Samridhi were transplanted in the field at a spacing of $45 \times 45 \mathrm{~cm}$. Different concentrations of Mel, viz. 0, 20, 40, 60 and 80 ppm were sprayed on the plant foliage at 15 days after transplanting (DAT) replicating each treatment four times. Leaf gas exchange and biochemical attributes were tested following the standard procedures. The Results showed the lowest stipulated rate of photosynthesis $\left(10.87 \mu\right.$ mole. $\left.\mathrm{m}^{-2} . \mathrm{sec}^{-1}\right)$, stomatal conductance $(301.44$
\end{abstract}




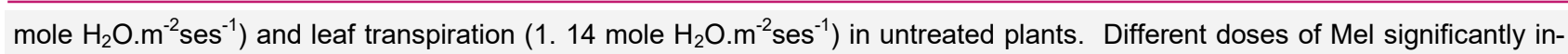
creased the values of these attributes and the highest values of photosynthesis $\left(18.63 \mu \mathrm{mole} \cdot \mathrm{m}^{-2} \cdot \mathrm{sec}^{-1}\right)$, stomatal conductance $\left(324.37\right.$ mmole. $\left.\mathrm{m}^{-2} \cdot \mathrm{ses}^{-1}\right)$ and leaf transpiration $\left(3.23 \mathrm{mmole} \cdot \mathrm{m}^{-2} \cdot \mathrm{ses}^{-1}\right)$ with Mel $60 \mathrm{ppm}$ were recorded. The alterations in different biochemical attributes were also evident due to foliar application of Mel and maximum leaf sugar $(77.0$ and $85.9 \mu \mathrm{g} / \mathrm{g})$, protein $(56.9$ and $77.3 \mu \mathrm{g} / \mathrm{g}$ ), total phenols $(260.1$ and $339.9 \mathrm{mg} / 100 \mathrm{~g})$, antioxidants (142.8 and $159.9 \mathrm{mg}$ GAE /100g DW) and MSI (94.89 and 97.43 percent) values with Mel 60ppm at 30 and 60DAT, respectively. Therefore, the present study signifies the useful effects of Mel in regulating the physio-biochemical properties of broccoli.

Keywords: Antioxidants, Broccoli, MDA, Melatonin, MSI, photosynthesis

\section{INTRODUCTION}

Broccoli (Brassica oleracea L.var Italica Plenck) is an important winter season exotic cole crop resembling cauliflower and grown for its edible head. It has large flower heads, usually green in color, arranged in a treelike structure branching out from a thick-edible stalk. Leaves surround the mass of flower heads. It is fat-free, low in sodium and calories, high in vitamin $C$ and good source of vitamin $A$, vitamin $B_{2}$ and calcium (Decoteau, 2000). Sprouting broccoli has about 130 times more vitamin A content than cauliflower and 22 times more than cabbage (Singh, 2007). It is a good source of carotenoids, glucosinolate and sulforaphane that are believed to be chemopreventive and associated with a decreased risk of human cancer (Higdon et al., 2007). At present broccoli is cultivated as an important cash crop in various states of the country and gaining popularity among the consumers and vegetable growers due to its good organoleptic properties, high nutritive value and great lucrative returns. Yield and quality improvement of any crop plant can be made possible through regulating the growth and physiological processes, especially photosynthesis (Simkin et al., 2019). The potential role of phytohormones in regulating the physiological processes, yield and quality of food crops, including vegetables have been well established. Melatonin (Mel) is a low molecular weight organic compound $\left(\mathrm{C}_{13} \mathrm{H}_{16} \mathrm{~N}_{2} \mathrm{O}_{2}\right)$ and has been regarded as nature's most versatile biological signal (Pandi-Perumal et al., 2006). In higher plants, Mel was first discovered in 1995 (Dubbels et al., 1995; Hattori et al., 1995) and its presence has now been clearly demonstrated in all plant organs, including the root, stem, leaf, flower, fruit, and seed at concentrations usually ranging from picograms to micrograms per gram of tissue (Ramakrishna et al., 2012). It has been reported to regulate various growth and physiological processes in plants with great potential for agricultural application (Nawaz et al., 2016; Zhang et al., 2017), especially under adverse environmental conditions.

Mel is reported to involve in the regulation of numerous physiological processes in plants such as growth, photosynthesis, rhizogenesis, chlorophyll stability and water balance (Ye et al., 2016; Zhang et al., 2017; Wei et al., 2015; Stephen et al., 2018), and also functions as an anti-stress agent against a variety of abiotic stresses by protecting plants against reactive oxygen species (ROS) (Reiter et al., 2015; Nawaz et al., 2016). It also functions as a plant regulator, with growth-promoting effects similar to those of indole acetic acid (IAA) (Hernandez and Arnao, 2008). Therefore, considering the potential scope of broccoli in improving the profitable yield and wide role of Mel in regulating the growth, physiological process and yield of crops, the present investigation was carried out to investigate the effect of Mel application on leaf gas exchange and physiobiochemical attributes in broccoli.

\section{MATERIALS AND METHODS}

The investigation was carried out at the Division of Basic Sciences and Humanities, Faculty of Horticulture, SKUAST-Kashmir during the year 2017. One month old uniform and healthy seedling of broccoli cv. Palam Samridhi was collected from the nursery, Division of Vegetable Science (SKUAST-K) and transplanted at a spacing of $45 \times 45 \mathrm{~cm}$ in a well prepared field. Different concentrations of Mel viz 0, 20, 40,60 and 80ppm were sprayed through hand spray on the foliage of plants at 15 days after transplanting (DAT). One plot constituted one sample unit and each treatment consisted of four plots with 6 plants per plot. Net photosynthetic rate, stomatal conductance and transpiration rate of broccoli leaves were measured at 60 DAT using TPS-2 photosynthesis measurement system. The TPS-2 is a high precision non-dispersive infrared gas analyzer used for the measurement of leaf photosynthesis, transpiration as well as stomatal conductance which operates on the 'open system principle' that includes an infrared source, a gold plated and highly polished sample cell and detector. The leaf was placed in a sealed enclosure with a window for illumination referred as the leaf cuvette. A measured flow of air was passed through the cuvette. The $\mathrm{CO}_{2} / \mathrm{H}_{2} \mathrm{O}$ concentration of the air entering and leaving were measured. To measure the concentration of $\mathrm{CO}_{2} / \mathrm{H}_{2} \mathrm{O}$ TPS-2 uses a single $\mathrm{CO}_{2}$ and water sensor and alternatively switches the reference and analysis air. From the rate flow of air and the change in concentration of $\mathrm{CO}_{2} / \mathrm{H}_{2} \mathrm{O}$, the assimilation and transpiration rate as well as stomatal resistance were calculated. Biochemical analysis of the leaf was done at 30 and 60 
DAT using standard procedures. For total soluble sugar $100 \mathrm{mg}$ of dried sample was hydrolysed with $5.0 \mathrm{ml}$ of $2.5 \mathrm{~N} \mathrm{HCl}$ by keeping it in a boiling water bath for 3 hours. After cooling at room temperature the content was neutralized with solid sodium bicarbonate until effervescence ceases and volume was made to $100 \mathrm{ml}$. Centrifuged the content at $500 \mathrm{~g}$ for 10 minutes and supernatant was collected. The amount of total soluble sugars was estimated by phenol sulphuric acid method (Dubois et al., 1956) colorimetrically. The extraction of protein was done by grinding $0.2 \mathrm{~g}$ of sample with a $0.1 \mathrm{M}$ phosphate buffer (ph 7.5) in a mortar and pestle. Centrifuged it and used the supernatant for protein estimation (Bradford 1976). Bovine Serum albumin (BSA) was used as protein standard. Total phenol was determined by Spectrophotometeric measurement of blue coloured complex by the reaction of phenols with phosphomolybdic acid in Folion Ciocalteur in alkaline medium (Bray and Thorpe, 1954). The total anti-oxidant capacity of the plant leaf extracts was measured by the method described by Prieto et al. (1999). The assay is based on the reduction of Mo $(\mathrm{VI})$ to Mo $(\mathrm{V})$ by the extract and subsequent formation of green phosphate/Mo (V) complex at acid pH. Malondialdehyde (MDA) content generated as a product of lipid peroxidation in the leaves of broccoli was estimated in different treatments according to Cakmak and Horst (1991). Leaf sample of $0.12 \mathrm{~g}$ were ground in $1.2 \mathrm{ml} 0.1 \%(\mathrm{w} / \mathrm{v})$ trichloroacetic acid (TCA), then centrifuged at $12000 \mathrm{~g}$ for $10 \mathrm{~min}$. Then $0.3 \mathrm{ml} 0.5 \%(\mathrm{w} / \mathrm{v})$ thiobarbituric acid (TBA) was added to $0.3 \mathrm{ml}$ of the supernatant. The resulting mixture was boiled at $100^{\circ} \mathrm{C}$ for $20 \mathrm{~min}$. The reaction was stopped by placing the reaction tubes in an ice bucket. The absorbance values were measured at 532, 600 and $450 \mathrm{~nm}$. The interference of soluble sugars in the samples at $A 532$ and $A 450$ was corrected by subtraction. The MDA content $\left(\mu \mathrm{mol} \mathrm{g}^{-1} \mathrm{FW}\right)$ was calculated as per the equation below :

$$
\text { MDA }(\mu \mathrm{mol} / \mathrm{g} \mathrm{FW})=6.45 \times\left(\mathrm{A}_{532}-\mathrm{A}_{600}\right)-0.56 \times \mathrm{A}_{450}
$$

Where,

$A_{532}, A_{600}$ and $A_{450}$ represent the absorbance of the mixture at 532,600 , and $450 \mathrm{~nm}$, respectively.

The leaf membrane stability index (MSI) was determined according to the method of Premachandra et al. (1990) as modified by Sairam (1994). Leaf discs (100 $\mathrm{mg}$ ) were thoroughly washed in running tap water followed by washing with double distilled water. Thereafter, the discs were heated in $10 \mathrm{ml}$ of double distilled water at $40^{\circ} \mathrm{C}$ for 30 minutes. Then electrical conductivity $\left(C_{1}\right)$ was recorded by EC (Electrical Conductivity) meter. Subsequently, the same samples were placed in a boiling water bath $\left(100^{\circ} \mathrm{C}\right)$ for 10 minutes and their electrical conductivity was also recorded $\left(\mathrm{C}_{2}\right)$. The MSI was calculated using equation below ):

$\mathrm{MSI}(\%)=1-\mathrm{C} 1 / \mathrm{C} 2 \times 100$
The data recorded on various variables were statistically analysed by using technique of analysis of variance and significance was determined as given by Panse and Sukhatme (1967).

\section{RESULTS AND DISCUSSION}

The process of carbon dioxide fixation (photosynthesis) and partitioning is believed to be a major determinant of crop yield. Data presented in table 1 revealed that untreated plants showed lowest stipulated rate of photosynthesis $\left(10.87 \mu\right.$ mole $\left.\mathrm{m}^{-2} \cdot \mathrm{sec}^{-1}\right)$, stomatal conductance $\left(301.44\right.$ mmole. $\left.\mathrm{m}^{-2} \cdot \mathrm{ses}^{-1}\right)$ and leaf transpiration (1.14 mmole. $\mathrm{m}^{-2} \cdot \mathrm{ses}^{-1}$ ) which was found to increase significantly due to foliar application of Mel. The increasing dose of Mel spray resulted in a corresponding increase in these attributes and got saturated at Mel application dose of $60 \mathrm{ppm}$ with a maximum rate of photosynthesis $\left(18.63 \mu\right.$ mole. $\left.\mathrm{m}^{-2} \cdot \mathrm{sec}^{-1}\right)$, stomatal conductance (324.37 mmole. $\left.\mathrm{m}^{-2} \cdot \mathrm{ses}^{-1}\right)$ and leaf transpiration $\left(3.23\right.$ mmole. $\left.\mathrm{m}^{-2} \cdot \mathrm{ses}^{-1}\right)$. However, the rate of photosynthesis was found to drop to $15.08 \mu$ mole $\mathrm{CO}_{2} \mathrm{~m}^{-2}$ / $\mathrm{sec}^{-1}$ at Mel 80ppm. Earlier studies also indicated that graded concentrations of Mel spray increased the photosynthetic attributes in tomato up to a certain level and then showed a decrease indicating the need for an optimum level (XioLong et al., 2017). Earlier workers have also communicated an increased rate of photosynthesis due to the application of Mel (Ye et al., 2016; Zhang et al., 2017) which may be attributed to an increase in the amount of photosynthetic pigments in the leaf (Mansha Gul et al., 2018; Stephen et al., 2018). It has been suggested (Lazar et al., 2013) that increased photosynthetic efficiency due to external application of Mel was the result of increased quantum yield of photochemistry of photosystem II. Increased stomatal conductance due to application of Mel has also been reported in earlier research (Ye et al., 2016). There have been a positive relationship of photosynthetic rate with stomatal conductance as well as leaf transpiration (Ancu et al., 2014).

Examination of the data presented in table 2 revealed that both leaf sugar $(39.5 \mu \mathrm{g} / \mathrm{g})$ as well as protein $(43.3$ $\mu \mathrm{g} / \mathrm{g}$ ) contents were minimum in untreated plants compared to Mel-treated plants and leaf sampling at 30DAT showed lower values of sugar $(55.8 \mu \mathrm{g} / \mathrm{g})$ as well as protein $(43.1 \mathrm{\mu g} / \mathrm{g})$ contents compared to the higher values of leaf sugar $(65.3 \mathrm{\mu g} / \mathrm{g})$ and protein $(66.7 \mu \mathrm{g} / \mathrm{g})$ contents at 60DAT. Comparison of foliar applied doses revealed that $60 \mathrm{ppm}$ of Mel was most efficient dose that produced 81.5 and $67.1 \mu \mathrm{g} / \mathrm{g}$ of sugar and protein contents. The role of Mel in improving the leaf soluble sugar contents may be attributed to its effect on enhanced photosynthesis rate ( $\mathrm{Ye}$ et al., 2016; Zhang et al., 2017), which might have resulted in accumulation of photosynthates in the form of soluble 
Table 1. Effect of foliar application of $\mathrm{Mel}(\mathrm{Mel})$ on leaf photosynthetic attributes and transpiration in broccoli.

\begin{tabular}{|c|c|c|c|}
\hline Treatments & $\begin{array}{l}\text { Net Photosynthetic Rate } \\
\left(\mu \mathrm{mole} \cdot \mathrm{m}^{-2} \cdot \mathrm{sec}^{-1}\right)\end{array}$ & $\begin{array}{l}\text { Stomatal conductance } \\
\left(\mathrm{mmole} \cdot \mathrm{m}^{-2} \cdot \mathrm{ses}^{-1}\right)\end{array}$ & $\begin{array}{l}\text { Transpiration rate } \\
\left(\text { mmole. }^{-2} \text { ses }^{-1}\right)\end{array}$ \\
\hline Mel Oppm & 10.87 & 301.44 & 1.14 \\
\hline Mel 20ppm & 12.87 & 312.32 & 1.92 \\
\hline Mel 40ppm & 14.43 & 317.28 & 2.12 \\
\hline Mel 60ppm & 18.63 & 324.37 & 3.23 \\
\hline Mel 80ppm & 15.08 & 315.68 & 2.40 \\
\hline$C D(p \leq 0.05)$ & 1.52 & 3.98 & 0.98 \\
\hline
\end{tabular}

Table 2. Effect of foliar application of Mel (Mel) on leaf sugar soluble protein contents in broccoli.

\begin{tabular}{llllllc}
\hline \multirow{2}{*}{ Treatment } & \multicolumn{3}{c}{ Sugar content $(\boldsymbol{\mu g} / \mathbf{g})$} & \multicolumn{3}{c}{ Soluble Protein content $(\boldsymbol{\mu g} / \mathbf{g})$} \\
\cline { 2 - 7 } & $\mathbf{3 0}$ DAT & $\mathbf{6 0}$ DAT & Mean & 30 DAT & 60 DAT & Mean \\
\hline Mel 0ppm & 33.6 & 45.3 & 39.5 & 31.4 & 55.1 & 43.3 \\
Mel 20ppm & 47.7 & 54.4 & 51.1 & 39.5 & 61.5 & 50.5 \\
Mel 40ppm & 59.2 & 68.7 & 64.0 & 43.7 & 68.2 & 56. \\
Mel 60ppm & 77.0 & 85.9 & 81.5 & 56.9 & 77.3 & 67.1 \\
Mel 80ppm & 61.3 & 72.1 & 66.7 & 44.0 & 71.3 & 57.7 \\
Mean & 55.8 & 65.3 & 60.5 & 43.1 & 66.7 & 54.9 \\
CD ( p $\leq 0.05)$ & 8.1 & 11.2 & - & 5.6 & 6.0 & - \\
\hline
\end{tabular}

Table 3. Effect of foliar application of Mel on leaf phenol and total antioxidant capacity in broccoli.

\begin{tabular}{lllllll}
\hline \multirow{2}{*}{ Treatment } & \multicolumn{3}{c}{ Phenols (mg/100g DW) } & \multicolumn{2}{c}{ Total antioxidant (mg GAE /100g DW) } \\
\cline { 2 - 7 } & 30 DAT & 60 DAT & Mean & 30 DAT & 60 DAT & Mean \\
\hline Mel 0ppm & 218.4 & 294.4 & 256.4 & 109.2 & 128.8 & 119 \\
Mel 20ppm & 239.1 & 313.3 & 276.2 & 117.6 & 135.2 & 126.4 \\
Mel 40ppm & 255 & 327.5 & 291.3 & 124.1 & 148.6 & 136.4 \\
Mel 60ppm & 260.1 & 339.9 & 300 & 142.8 & 159.9 & 151.4 \\
Mel 80ppm & 254.6 & 337.5 & 296.1 & 131.5 & 140.1 & 135.8 \\
Mean & 245.4 & 322.5 & - & 125.0 & 142.5 & - \\
CD $(p \leq 0.05)$ & 6.4 & 7.1 & & 11.9 & 10.3 & \\
\hline
\end{tabular}

sugar. Zhao et al. (2015) reported that exogenous applications of Mel regulated carbohydrate metabolism in Arabidopsis thaliana by modulating the sugar metabolism-related genes during plant development. Wei et al. (2014) suggested that Mel probably achieved its growth promotional roles in soybean through enhancement of genes involved in carbohydrate metabolism. Improved leaf protein content due to the application exogenous application of Mel has also been reported in the literature (Zhang et al., 2017; Liang et al., 2018).

Present study revealed that total phenol (218.4mg/100gDW; $294.4 \mathrm{mg} / 100 \mathrm{gDW})$ and antioxidant
(109.2 mg GAE /100g DW; 128.8 mg GAE /100g DW) contents (Table 3 ) obtained at 30 and 60 DAT, respectively under control were increased significantly due to foliar application of Mel. The highest values of total phenol $(300.0 \mathrm{mg} / 100 \mathrm{gDW})$ and antioxidants (151.4mg GAE /100g DW) were recorded with 60ppm of Mel. However, these values were found higher (322.5 $\mathrm{mg} / 100 \mathrm{~g} \mathrm{DW} ; 142.5 \mathrm{mg}$ GAE $/ 100 \mathrm{~g} \mathrm{DW})$ at 60DAP compared to lower values $(245.4 \mathrm{mg} / 100 \mathrm{~g}$ DW; 125.0 mg GAE /100g DW) at 30DAT. Earlier studies verified the increased level of total phenols due to exogenous application of Mel in Vigna radiate (Szafrańska et al., 
Gul, M. et al. / J. Appl. \& Nat. Sci. 13(2), 791 - 797 (2021)

Table 4. Effect of foliar application of Mel (Mel) on Malondialdehyde (MDA) Content and Membrane stability index (MSI) in broccoli.

\begin{tabular}{|c|c|c|c|c|c|c|}
\hline \multirow{2}{*}{ Treatment } & \multicolumn{2}{|c|}{ MDA ( $\mu$ mol MDA/g FW) } & \multirow[t]{2}{*}{ Mean } & \multicolumn{2}{|c|}{ MSI (\%) } & \multirow[t]{2}{*}{ Mean } \\
\hline & 30 DAT & 60 DAT & & 30 DAT & 60 DAT & \\
\hline Mel Oppm & 0.37 & 0.31 & 0.34 & $72.58(8.52)$ & $79.32(8.91)$ & 75.95 \\
\hline Mel 20ppm & 0.31 & 0.28 & 0.30 & $78.67(8.87)$ & $85.11(9.23)$ & 81.89 \\
\hline Mel 40ppm & 0.29 & 0.26 & 0.28 & $81.66(9.04)$ & $90.65(9.52)$ & 86.12 \\
\hline Mel 60ppm & 0.26 & 0.19 & 0.23 & $94.89(9.74)$ & $97.43(9.87)$ & 96.16 \\
\hline Mel 80ppm & 0.25 & 0.20 & 0.23 & $85.69(9.26)$ & $92.33(9.61)$ & 89.01 \\
\hline Mean & 0.25 & 0.2 & 0.27 & 85.69 & 92.33 & 85.83 \\
\hline$C D(p \leq 0.05)$ & 0.03 & 0.01 & - & 0.31 & 0.11 & - \\
\hline
\end{tabular}

Figures in parenthesis are square root transformed data for the purpose of statistical analysis

2014). Mel has been reported to have antioxidant potential itself (Arnao and Hernandez, 2015) and its exogenous application was found to enhance the total antioxidant capacity in several studies (Gao et al., 2018; Huang et al., 2019).

Results with regard to MDA and MSI (Table 4) indicated that untreated plants showed highest MDA content $(0.37 \& 0.31 \mu \mathrm{mol} \mathrm{MDA} / \mathrm{g} \mathrm{FW})$ both at 30 and 60DAT whereas foliar spray of Mel significantly reduced the leaf MDA content and minimum values at 30 and 60DAT were recorded with Mel 60ppm (0.26 \&0.19 $\mu \mathrm{mol} \mathrm{MDA} / \mathrm{g} \mathrm{FW})$. However, in contrast to MDA content the electrolyte analysis of the leaves showed lowest $\mathrm{MSI}$ (72.58 and $79.32 \%$ ) with zero ppm of Mel and highest MSI (94.89 and 97.43\%) with 60 ppm of Mel, respectively at 30 and 60 DAT. In general, leaves sampled at 30 DAT showed higher values of MDA contents ( $0.25 \mathrm{~mol} \mathrm{MDA} / \mathrm{g} \mathrm{FW})$ coupled with the lower values $\mathrm{MSI}(85.69 \%)$ as compared to MDA value of $0.2 \mathrm{~mol} \mathrm{MDA} / \mathrm{g} \mathrm{FW}$ and $\mathrm{MSI}$ value of $92.33 \%$ of leaves sampled at 60DAT. The study supports the earlier views that as a powerful antioxidant Mel in addition to direct scavenging of ROS generated as a by-product of metabolic reactions also improve the plant's antioxidant system (Yu et al., 2018). Improved level of antioxidants caused by exogenous application of Mel have also been reported by earlier workers in different crops (Gao et al., 2018; Huang et al., 2019: Li et al., 2018). Our results are also concordant with previous reports that Mel facilitated the maintenance of membrane functions by protecting the fatty acid peroxidation ( $\mathrm{Li}$ et al., 2012; Zhang et al., 2014). Further, the depression in MDA content due to Mel treatment in broccoli showed the reduction of lipid peroxidation leading to improved membrane integrity. Our results were also in agreement with those of Jiang et al. (2016) who stated that the application of Mel in maize resulted in a decreased contents of electrolyte leakage and malondialdehyde content compared with untreated plants.

\section{Conclusion}

Foliar application of Mel (@ 60 ppm at 15 days after transplanting resulted in significant improvement of gas exchange parameter including photosynthesis. Significant alterations in leaf sugar, protein, phenols, antioxidants and MSI were also evident due to foliar applications of Mel @ 60ppm. Further, leaves sampled at 30 DAT showed relatively lower values of these attributes compared to the leaves sampled at 60DAT, probably because of the altered source and sink ratio at the time of head development. However, in contrast to antioxidant and MSI, leaf MDA content showed the least value at 60ppm compared to other treatments, including control. It was also higher at 30 days of sampling compared to 60 days of sampling. Therefore, the present study suggested that Mel's judicious use can help improve the physiological and biochemical attributes of plant that may result in an improved head yield and quality of broccoli.

\section{Conflict of interest}

The authors declare that they have no conflict of interest.

\section{REFERENCES}

1. Ancu, S., Chitu, C., Marin, F.C., Ancu, I. and Plopa, C. (2014). Correlation of stomatal conductance with photosymthetic capacity of six walnut cultivars from the national assortment. South-west J. Hortic. Biol. Environ., 5: 1-10.

2. Arnao, M.B. and Hernandez J. (2015). Functions of melatonin in plants: a review. J. Pineal Res., 59:133-50, DOI: $10.1111 /$ jpi.12253

3. Bradford, M.M. (1976). A rapid and sensitive method for the quantitation of microgram quantities of protein utilizing the principle of protein-dye binding. Anal. Biochem., 72: 248-254

4. Bray, H.G. and Thorpe, W.V. (1954). Analysis of phenolic compounds of interest in metabolism. Methods Biochem. Anal., $\quad 52$ : $\quad 1-27, \quad$ https://doi.org/10.1002/9780 470110171.ch2

5. Cakmak, I. and Hors, W.J. (1991). Effect of aluminum on lipid peroxidation, superoxide dismutase, catalase and 
peroxidase activities in root tips of soybean (Glycine max). Physiol. Plant., 83: 463 - 468, https://doi.org/10.1111/ j.1399-3054.1991.tb00121.x

6. Decoteau, D.R. (2000). Vegetable Crops. Upper Rever Company. New Jersey. U.S.A.

7. Dubbels, R., Reiter, R.J., Klenke, E., Goebel, A., Schnakenberg, E., Ehleers, C., Schiwara, H.W. and Schloot, W. (1995). Melatonin in edible plants identified by radioimmunoassay and by high performance liquid chromatography-mass spectrometry. J. Pineal Res., 18: 28-31, DOI: 10.1111/j.1600-079x.1995.tb00136.x

8. Dubois, M., Gilles, K.A., Harmilton, J.K., Rebers, P.A. and Smith, F. (1956). Colorimetric method for determination of sugars and related substances. Anal. Chem., 28: 350-356, https://doi.org/10.1021/ac60111a017

9. Gao, W., Zhang, Y., Feng, Z., Bai, Q., He, J. and Wang, $Y$. (2018). Effect of melatonin on antioxidant capacity in naked oat seedlings under drought stress. Molecules, 23; 1580, DOI: 10.3390/molecules23071580

10. Hattori, A., Migitaka, H., ligo, M., Itoh, M., Yamamoto, K., Ohtani-Kaneko, R., Hara, M., Suzuki, T., Reiter, R.J. (1995). Identification of melatonin in plants and its effects on plasma melatonin levels and binding to melatonin receptors in vertebrates. Biochem. Mol. Biol. Int., 35: 627634.

11. Hernandez-Ruiz, J. and Arnao, M.B. (2008). Distribution of melatonin in different zones of lupin and barley plants at different ages in the presence and absence of light. J. Agr. Food Chem., 56: 10567-10573, https://doi.org/10.1021/ jf8022063

12. Higdon, J.V., Delage, B., Williams, D.E. and Dashwood R.H. (2007). Cruciferous vegetables and human cancer risk: epidemiologic evidence and mechanistic basis. Pharmacol. Res., 55 (3): 224-236, doi: 10.1016/ j.phrs.2007.01.009.

13. Huang, B., Chen, Y., Zhao, Y., Ding, C., Liao. J., Hu, C., Zhou, L., Zhang, Z., Yuan, S., and Yuan, M. (2019). Exogenous melatonin alleviates oxidative damages and protects photosystem II in maize seedlings under drought stress. Front. Plant Sci., https://doi.org/10.3389/ fpls.2019.00677

14. Jinag, X., Li, H., and Song, X. (2016). Seed priming with melatonin effects on seed germination and seedling growth in maize under salinity stress. Pak. J. Bot., 48: 1345-1352.

15. Lazar, D., Murch, S.J., Beilby, M..J and Khazaaly S. (2013). Exogenous melatonin affects photosynthesis in characeae Chara australis. Plant Signal. Behav., 8: e23279, doi: 10.4161/psb.23279

16. Li, C., Wang, P., Wei, Z., Liang, Liu, C., Yin, L., Jia, D., Fu., M. and Ma, F. (2012). The mitigation effects of exogenous melatonin on salinity-induced stress in Malus hupehensis. J. Pineal Res., 53: 298-306, doi: 10.1111/ j.1600-079X.2012.00999.x

17. Li, J., Arkorful, E., Cheng, S., Zhou, Q., Li, H., Chen, X., Sun, K. and Li, X. (2018). Alleviation of cold damage by exogenous application of melatonin in vegetatively propagated tea plant (Camellia sinensis (L.) O. Kuntze). Sci. Hortic., 238: 356-62, https://doi.org/10.1016/j.scien ta.2018.04.068

18. Liang, D., Shen, Y., Ni, Z., Wang, Q., Lei, Z., Xu, N., Deng, Q., Lin, L., Wang, J. Lv, X., and Xia, H. (2018).
Exogenous melatonin application delays senescence of kiwifruit leaves by regulating the antioxidant capacity and biosynthesis of flavonoids. Front. Plant Sci., 9:426, https:// doi.org/10.3389/fpls.2018.00426.

19. Mansha, Gul, Khan, F.A., Wani, S.A., Bhat, S.A., Mir, S.A., Malik, A.A., Kumar, A. and Narayan S. (2018). Foliar application of melatonin modulates the growth and photosynthetic pigments in broccoli cv. Palam Samridhi. SKUAST J. Res., 20: 193-198.

20. Nawaz, M.A., Huang, Y., Bie, Z., Ahmed, W., Reiter, R.J., Niu, M. and Hameed, S. (2016). Melatonin: current status and future perspectives in plant science. Front. Plant Sci., 6: 1230, https://doi.org/10.3389/fpls.2015.01230.

21. Pandi-Perumal, S.R., Srinivasan, V., Maestroni, G.J.M., Cardinaldi, D.P., Poeggeler, B. and Hardeland, R. (2006). Melatonin: nature's most versatile biological signal? The FEBS J., 273: 2813-38, DOI: 10.1111/j.17424658.2006.05322.x

22. Panse, V.G. and Sukhatme, P.V. (1967). Statistical Methods for Agricultural Workers, 2nd Edition, Indian Council of Agricultural Research, New Delhi.

23. Premachandra, G.S., Saneoka, H., Fujita, K., and Ogata, S. (1990). Cell membrane stability an indicator of drought tolerance as affected by applied $\mathrm{N}$ in soybean. J. Agric. Soc. Camp., 115: 63-66, DOI: https://doi.org/10.1017/ S0021859600073925

24. Prieto, P., Pineda, M. and Aguilar, M. (1999). Spectrophotometric quantitation of antioxidant capacity through the formation of a phosphomolybdenum complex: Specific application to the determination of vitamin E. Anal. Biochem., 269: 337-341, DOI: 10.1006/ abio.1999.4019.

25. Ramakrishna, A., Giridhar, P., Sankar, K.U. and Ravishankar, G.A. (2012). Melatonin and serotonin profiles in beans of Coffea species. J. Pineal Res., 52: 470-476, DOI: 10.1111/j.1600-079X.2011.00964.X

26. Reiter, R.J., Tan, D., Zhou, Z., Cruz, M.H.C., FuentesBroto, L. and Galano, A. (2015). Phytomelatonin: assisting plants to survive and thrive. Molecules, 20: 7396-7437, doi: $10.3390 /$ molecules20047396

27. Sairam R.K. (1994). Effect of moisture stress on physiological activities of. two contrasting wheat genotypes. Indian J. Exp. Biol., 31:551-553

28. Simkin AJ, Lopez-Calcagno PE and Raines CA. (2019). Feeding the world: improving photosynthetic efficiency for sustainable crop production. J. Exp. Bot., 70 (4): 11191140, 2019 doi:10.1093/jxb/ery445

29. Singh, N.P. (2007). Basic concept of vegetable science. International Book Distributing Co. Lucknow, pp: 444.

30. Stephen, K., Khan, F.A., Bhat, S.A., Narayan, S., Mir, S.A., Mir, M.S., Hussain, K., Mansha Gul, Asma K., Irtiza, S., Hussain, S.M. and Lone, S.A. (2018). Optimizing priming concentration and duration of various priming agents for improved seed germination in chilli (Capsicum annum L.). J. Pharmacogn. Phytochem., 7: 2680-2693.

31. Szafrańska, K., Reiter, R.J., and Posmyk, M.M. (2017). Melatonin Improves the Photosynthetic Apparatus in Pea Leaves Stressed by Paraquat via Chlorophyll Breakdown Regulation and Its Accelerated de novo Synthesis. Front. Plant Sci., 8: 878, https://doi.org/10.3389/fpls.2017.00878

32. Wei, W., Li, Q.T., Chu, Y.N., Reiter, R.J., Yu, X.M., Zhu, D.H., Zhang, W.K., Ma, B., Lin, Q., Zhang J.S. and Chen 
S.Y. (2015). Melatonin enhances plant growth and abiotic stress tolerance in soybean plants. J. Exp. Bot., 66: 695707, doi: 10.1093/jxb/eru392

33. XioLong, Y., Hui, X., TiaLai, L. and Rui, W. (2017). Effects of exogenous melatonin on photosynthesis of tomato leaves under drought stress. Scientia Agricultura Sinica, 50 (16): 3186-3195, DOI: 10.3864/j.issn.05781752.2017.16.013

34. Ye, J., Wang, S., Deng, X., Yin, L., Xiong, B. and Wang, $X$. (2016). Melatonin increased maize (Zea mays L.) seedling drought tolerance by alleviating drought-induced photosynthetic inhibition and oxidative damage. Acta Physiol. Plant., 38:48; DOI 10.1007/s11738-015-2045-y

35. Yu, K., Deng, S.L., Sun, T.C., Li, Y.Y. and Liu, Y.X. (2018). Melatonin regulates the synthesis of steroid hormones on male reproduction: a review, Molecules, 23: (2):
447, DOI: 10.3390/molecules23020447

36. Zhang, H.J., Zhang, N., Yang, R.C., Wang, L., Sun, Q.Q, Li, B.D., Cao, Y.Y., Weeda, S., Zhao, B., Ren, S. and Guo, Y.D. (2014). Melatonin promotes seed germination under high salinity by regulating antioxidant systems, ABA and GA4 interaction in cucumber (Cucumis sativus L.). J. Pineal Res., 57: 269-279, https://doi.org/10.1111/jpi.12167

37. Zhang, R., Sun, Y., Liu, Z., Jin, W. and Sun, Y. (2017). Effects of melatonin on seedling growth, mineral nutrition, and nitrogen metabolism in cucumber under nitrate stress. J. Pineal Res., 62: e12403, doi: 10.1111/jpi.12403.

38. Zhao, H., Su, T., Huo, L., Wei, H., Jiang, Y., Xu, L. and Ma, F. (2015). Unveiling the mechanism of melatonin impacts on maize seedling growth: sugar metabolism as a case. J. Pineal Res., 59: 255-266, doi: 10.1111/ jpi.12258. 